\title{
Krzysztof Warchałowski
}

"Separacja w prawie polskim", Kazimierz Piasecki, Warszawa 2000 : [recenzja]

Ius Matrimoniale 6 (12), 241-244

2001

Artykuł został zdigitalizowany i opracowany do udostępnienia w internecie przez Muzeum Historii Polski w ramach prac podejmowanych na rzecz zapewnienia otwartego, powszechnego i trwałego dostępu do polskiego dorobku naukowego i kulturalnego. Artykuł jest umieszczony w kolekcji cyfrowej bazhum.muzhp.pl, gromadzącej zawartość polskich czasopism humanistycznych i społecznych.

Tekst jest udostępniony do wykorzystania w ramach dozwolonego użytku. 
Ius Matrimoniale

6 (12) 2001

\section{Kazimierz Piasecki, Separacja w prawie polskim, Wydawnictwo Prawnicze, Warszawa 2000, ss.110.}

Prezentowana książka składa się z XII rozdziałów poruszających temat separacji Polsce i innych krajach europejskich. Możemy dokładnie poznać genezę powstania instytucji separacji, jej przesłanki, możliwości orzeczenia lub zniesienia oraz skutków prawnych przejawiających się w różnych dziedzinach prawa prywatnego i publicznego.

W rozdziale I pt.: „Rodzaje malżeństw wedlug prawa polskiego” Autor zapoznaje czytelnika $\mathrm{z}$ samą instytucją małżeństwa na kanwie prawa polskiego, co stanowi fundament do przedstawienia i dogłębnego zrozumienia separacji prawnej. Dowiadujemy się, jak kształtowały się przepisy dotyczące malżeństwa cywilnego i form jego zawierania od okresu po II wojnie światowej, przez lata 1968-1989 a skończywszy na Ustawie z dnia 24 lipca 1998 r. o zmianie ustaw - Kodeks rodzinny i opiekuńczy, Kodeks postępowania cywilnego, Ustawie o stosunku Państwa do Kościola Katolickiego w Rzeczpospolitej Polskiej z dnia 17 maja 1989 r. oraz innych aktach normatywnych. Autor stara się ukazać, że funkcjonujący w Polsce system prawny charakteryzuje się dualizmem systemów zawierania małżeństw (małzeństwo cywilne i kościelne), co jest wlaściwe nie tylko dla naszego kraju, ale wręcz popularne na całym świecie.

Rozdzial II pt.: "Geneza koncepcji separacji. Uwagi prawnoporównawcze” dotyczy skutków, jakie pociąga za sobą separacja na płaszczyźnie wyznaniowej oraz w sferze państwowego systemu prawnego. Autor zwraca uwagę, że prawo kanoniczne $w$ przeciwieństwie do państwowego odrzuca instytucję rozwodu. Stąd dualizm unormowań: z jednej strony tylko separacja, z drugiej z separacją może konkurować rozwód. Analizę ubogaca komparatystyczne porównanie polskich rozwiązań z regulacjami przyjętymi w wybranych krajach europejskich m. in.: we Francji, Księstwie Monako i Wielkiej Brytanii.

W rozdziale III pt.: „Separacja wedlug prawa kanonicznego" omówiona zostala separacja prawna jako instytucja prawa kanonicznego. Autor podaje definicje separacji kanonicznej oraz analizuje przepisy prawa kościelnego zawarte w KPK dotyczące separacji (kan 1151-1155). Analizę ubogaca częśc historyczna ukazująca rozwój tej instytucji w prawie kanonicznym od okresu wczesnego średniowiecza aż po czasy współczesne. 
Rozdział IV nosi tytuł: „Polskie koncepcje separacji w latach 1918-1.939 oraz projekty uregulowania separacji małżeństwa". Po odzyskaniu przez Polskę niepodległości w 1918 r. na ziemiach państwa polskiego obowiązywały różne systemy prawne odziedziczone po państwach zaborczych. Każdy z tych systemów prawnych zajmował odmienne stanowisko dotyczące istoty małżeństwa, jednak instytucja separacji małżeńskiej znana była wszystkim trzem ustawodawstwom. Do zadań ustawodawcy polskiego należało zatem ujednolicenie systemu prawnego również w zakresie dotyczącym prawa małżeńskiego, a co za tym idzie instytucji separacji prawnej.

Pierwszy projekt separacji małżeńskiej wraz z projektem ujednoliconego prawa małżeńskiego został przedłożony przez Komisję Kodyfikacyjną w dniu 28 maja 1929 r. Projekt legalizował w polskim prawie cywilnym zarówno instytucję separacji jak i rozwodu. Naczelną ideą postulowanych rozwiązań prawnych była jednak zasada trwałości związku malżeńskiego. Stąd jako zalety instytucji separacji nad rozwodem projekt wymieniał:

- możliwość powrotu malżonków do wspólnego pożycia bez utrudnień proceduralnych,

- niemożliwość zawarcia przez małżonków nowych związków z osobami trzecimi,

- dluższy czas do zastanowienia nad powzięciem ostatecznej decyzji,

- poszanowanie przekonań małżonków w kwestii nierozerwalności małżeństwa.

Projekt z 1929 r. nie został uchwalony ponieważ spotkał się z ostrym sprzeciwem wielu środowisk, w tym także kręgów katolickich, które domagały się przyjęcia wyznaniowego charakteru małżeństwa.

Rozdział V pt.: „Zupełny rozkład pożycia małżeńskiego” traktuje o pozytywnej przesłance orzeczenia separacji, jaką jest zupełny rozkład pożycia małżonków. Pojęcie „zupełnego" rozkładu pożycia było wielokrotnie wyjaśniane w orzecznictwie Sądu Najwyższego. Autor przywołuje niektóre orzeczenia tegoż sądu a wśród wielu przesłanek zupełności rozkładu pożycia małżeńskiego wymienia:

- zerwanie współżycia

- nie rozpoczęcie współżycia

- chorobę psychiczna

- sporadyczne stosunki fizyczne

- różnicę charakterów i usposobień małżonków

- związanie się matżonka z inna osobą itd.

W rozdziale VI pt.: „Przesłanki negatywne separacji” omówiona została negatywna przesłanka separacji jaką jest sprzeczność jej orzecze- 
nia z dobrem wspólnych małoletnich dzieci małżonków (art. $61 \S 2$ k.r.o.). Autor odwołuje się do apelu skierowanego przez Zgromadzenie Parlamentarne Europy do Rady Europy i do jej państw członkowskich w rekomendacjach 1071 i 1074 o zapewnieniu ochrony dobra dziecka. W rozdziale tym zwraca uwage poczynione w sposób bardzo wnikliwy $i$ interesujący rozważanie o tym, co jest lepsze dla małoletniego dziecka - rozwód czy separacja jego rodziców.

W kolejnym VII rozdziale monografii pt.: „Wina zupełnego rozkładu pożycia małżeńskiego" porusza Autor zagadnienie winy w sprawach o orzeczenie separacji malżeńskiej. Wnikliwej analizie poddane zostały art. 57 oraz $61 \S$ l, k.r.o., które dają podstawę sądowi do wypowiedzenia się, który $\mathrm{z}$ małżonków ponosi winę rozkładu pożycia. Przy ocenie winy istotne znaczenie ma zagadnienie przyczyn i ich charakteru. Swoje stanowisko Autor popiera wieloma orzeczeniami Sądu Najwyższego wydanymi w tej sprawie.

Rozdział VIII pt.: „Separacja na zgodny wniosek małżonków” zawiera omówienie jednego z rodzajów separacji prawnej, jaką jest tzw. separacja zgodna. Przepisy dotyczące separacji na zgodne żądanie małżonków zostały zawarte w art. $5671-5675$ k.p.c. W dalszej części rozdziału Autor zajmuje się trybem postępowania sądowego właściwym dla tego rodzaju separacji.

W następnym, IX rozdziale opracowania zatytułowanym.: "Skutki prawne orzeczonej prawomocnie separacji” Autor książki przedstawia skutki prawne separacji, podkreślając, że:

- nie rozrywa węzła małżeńskiego,

- małżonkowie nie mają obowiązku współżycia,

- małżonek nie może po raz kolejny prawomocnie zawrzeć małżeństwa,

- orzeczenie separacji powoduje powstanie rozdzielności majątkowej,

- sąd może orzec przeprowadzenie podziału majątku wspólnego,

- małżonkowie mają równe udziały w majątku wspólnym,

- małzonkowie zobowiązani są do wzajemnej pomocy,

- występuje obowiązek alimentacyjny,

W rozdziale X pt.: „Procesowe aspekty postępowania w sprawach o orzeczenie separacji malżeństwa" omówione zostały przepisy formalnoprawne dotyczące separacji prawnej, a więc separacja przedstawiona została od strony postępowania procesowego. Autor omawia sprawę właściwości sądu, formalności związanych z pozwem, opłat sądowych itp.

Rozdział XI pt.: „Zniesienie separacji i jego skutki prawne” dotyczy skutków prawnych jakie pociąga za sobą zniesienie separacji. Mówi o tym art. $616 \S 1$ k.r.o., który w niniejszym rozdziale poddany został szczegółowej analizie. 
Zniesienie separacji prawnej może odbyć się tylko przed sądem w postępowaniu nieprocesowym a postanowienie o jej zniesieniu sąd wydaje tylko po przeprowadzeniu rozprawy.

Rozdział XII pt.: „Zagadnienia kolizyjne prawne oraz z zakresu jurysdykcji krajowej i uznawania orzeczeń zagranicznych". W rozdziale tym poruszony został temat umów międzynarodowych zawartych przez państwo polskie $w$ aspekcie uzyskiwania separacji prawnej przez małżonków z których jedno nie jest obywatelem polskim. Jako ilustracja przyjmowanych rozwiązań jest umieszczony na końcu rozdziału tekst Umowy między Polską Rzeczpospolitą Ludową a Republiką Francuską dotyczący m. in. spraw małżeńskich.

Monografia Kazimierza Piaseckiego stanowi kompleksowe opracowanie problematyki dotyczącej separacji małżonków - nowej instytucji prawnej wprowadzonej do polskiego systemu prawnego w $1999 \mathrm{r}$.

Prezentując ewolucję, jaką przeszła separacja począwszy od czasów średniowiecza, aż po XX wiek, i to nie tylko w Polsce ale również w innych państwach europejskich, Autor ukazał czytelnikowi historię i stan wspólczesny instytucji separacji prawnej.

Uwagę zwraca uwzględnienie szerokiego wachlarza regulacji uwzględniony zarówno $z$ zakresu zagadnień materialnoprawnych, jak i postępowania sądowego. Ponadto instytucja separacji została przedstawiona zarówno pod kątem prawa cywilnego, jaki i prawa kanonicznego.

Książka została napisana bardzo przystępnym językiem, a wiele zagadnień zostało zobrazowanych przykładami, co pozwala na lepsze zrozumienie niełatwych często zagadnień.

Publikację uzupełniają dolączone na końcu wzory pism procesowych związanych $\mathrm{z}$ separacją oraz odpowiednie przepisy zamieszczone w formie wyciągów z aktów normatywnych. Pozwalają one na zapoznanie się $z$ tematem od strony praktycznej.

Książka adresowana jest do szerokiego grona czytelników, zwłaszcza studentów wydziałów prawa i prawa kanonicznego. Może okazać się także bardzo fachową pomocą dla prawników prowadzących praktykę sądową zwłaszcza z zakresu spraw małżeńskich i rodzinnych. Polecam tę monografię wszystkim zainteresowanym problematyką separacji, gdyż dzieło to stanowi doskonały przewodnik pozwalający w sposób bardzo przystępny na zapoznanie się z instytucją separacji małżeńskiej i zrozumienie racji jej orzekania przez sądy polskie.

Ks. Krzysztof Warchatowski 